\title{
Linguistic Relativity in Words Formed by Means of Prefixation in English and Albanian Language
}

\author{
Doct. MA Olsa Xhina \\ Department of Foreign Languages, Faculty of Education, \\ "Aleksander Moisiu" University, Albania \\ E-mail: olsa.xhina@gmail.com
}

\section{Doi:10.5901/jesr.2014.v4n1p205}

\begin{abstract}
There are a lot of difficulties deriving from the diversity of cultures, history, languages, when people from different ethnic and linguistic backgrounds come into contact and communicate with each-other. This idea led to the theory of linguistic relativity, which was inspired by Edward Sapir's hypothesis. It gives priority to the necessity of understanding linguistic and cultural relativity. Linguists claim that English speakers think about the world in different ways from Albanian ones. Albanian language is spoken by a small population and its lexicon is rather smaller than that of the English language, and for this reason, during the translation process lexical or semantic equivalents are often unavailable. This paper contrastively analyses the English and Albanian languages in terms of linguistic relativity in derived words by means of prefixation in English and Albanian language. The paper treats problems that occur during translation process in the words formed by means of prefixation. We will consider the locative prefixes, the negative prefixes, the prefixes of attitude, reservative prefixes, pejorative prefixes, prefixes of size, degree and status, prefixes of time and order, prefix of repetition, as Quirk classifies them semantically.
\end{abstract}

\section{Introduction}

A lot of difficulties derive from the diversity of cultures, languages, history, when people from different ethnic and linguistic backgrounds come into contact and communicate with each-other. This idea led to the theory of linguistic relativity, which was inspired by Edward Sapir's hypothesis according to which "No two languages are ever sufficiently similar to be considered as representing the same social reality". $(1949,69)$. Saussure supported this hypothesis by his theory on the arbitrary nature of the verbal sign. Saussure's theory states that there is no inner logic relationship between 'the signified' and the 'signifier'. Because the sign is arbitrary, it follows no law other than that of tradition, and because it is based on tradition, it is arbitrary. $(1986,74)$ Thus, in the context of globalization linguistic relativity is inevitable. (Swoyer 2003) The differences can be seen in languages which do not belong to the same family such as English and Albanian language. The English language belongs to the Anglo-Frisian sub-group of the West Germanic branch of the Germanic family whereas the Albanian Language belongs to the family of Indo-European Languages, along with IndoIranian languages, Greek language, Romance languages, Slavonic languages, Germanic languages, etc. It constitutes a separate branch in this family of languages and is not originally associated to any of the modern Indo-European languages. The Indo-European origin of the Albanian language and the place it occupies in the family of Indo-European languages was determined and proved in the middle of the 19th century, following studies in the comparative historical linguistics. It was primarily the merit of one of the leading founders of this linguistic direction, the eminent German scholar Franz Bopp, who proved scientifically that the Albanian language belonged to the family of the Indo-European languages. Franz Bopp dedicated to this issue a special work entitled "Ueber das Albanesische in sinen verwandtschaft lichen Bezichungen", published in 1854. (Webster's new $20^{\text {th }}$ Century Dictionary, 1975).

A lot of thinkers have urged that large differences in language lead to large differences in experience and thought. They hold that each language embodies a worldview, with quite different languages embodying quite different views, so that speakers of different languages think about the world in quite different ways. This view is sometimes called the Whorf-hypothesis or the Whorf-Sapir hypothesis, after the linguists who made it famous. But the label linguistic relativity, which is more common today, has the advantage that makes it easier to separate the hypothesis from the details of Whorf's views, which are an endless subject of exegetical dispute (Gumperz and Levinson, 1996) In terms of translation, the theory of linguistic relativity underlines that there is no possibility of translating from one language into another. Nevertheless, translators accept that most often what is said or written in the source language can be written or spoken even in the target language. (Ramushaj 2004, 337). According to the Albanian linguist Rami Memushaj this thesis is not 
acceptable, even for negating the cultural borrowings among people with different languages. Cultures, like people, give and take between them.

The paper treats problems that occur during translation process in the words formed by means of prefixation. We will consider the locative prefixes, the negative prefixes, the prefixes of attitude, reservative prefixes, pejorative prefixes, prefixes of size, degree and status, prefixes of time and order, prefix of repetition, as Quirk classifies them semantically (Quirk, 1985).

\section{The Linguistic Relativity Hypothesis}

Like many other relativistic themes, the hypothesis of linguistic relativity became a serious topic of discussion in lateeighteenth and nineteenth-century Germany, particularly in the work of Johann Georg Hamann (1730-88), Johann Gottfried Herder (1744-1803), and Wilhelm von Humboldt (1767-1835). It was later defended by thinkers as diverse as Ernst Cassirer and Peter Winch. However, the hypothesis came to prominence though the work of Edward Sapir and his student Benjamin Lee Whorf. Indeed, it is often called the Sapir-Whorf hypothesis, or simply the Whorf hypothesis. (Swoyer 2003).

According to Swoyer interesting versions of the linguistic relativity hypothesis embody two claims. The first claim leads to the linguistic diversity, that is languages, especially members of quite different language families, differ in important ways from one another. The second claim is linguistic influence on thought; the structure and lexicon of one's language influences how one perceives and conceptualizes the world, and they do so in a systematic way. By this two claims speakers of English and Albanian language, as two quite different languages, think about the world in quite different ways. There is a clear sense in which the thesis of linguistic diversity is uncontroversial. Even if all human languages share many underlying, abstract linguistic universals, there are often large differences in their syntactic structures and in their lexicons. (Swoyer 2003) As for the second claim it is more controversial, but since linguistic forces could shape thought in varying degrees, it comes in more and less plausible forms.

The Albanian linguist believes that the linguistic relativity, according to which what is said or written in the source language cannot be written or spoken in the target language, carries a wide range of negative consequences, not only theoretically but also practically. It is true that languages do have differences, otherwise there wouldn't be so many of them, but they do also have mutual characteristics. Similarities among them derive above all from the inherited part of the language, that is the linguistic universals; second, because of the fact that in all languages there are words, borrowed expressions and syntactical formations.

This hypothesis is inconsistent with the facts of bilingualism, because, according to it, bilingual individuals would have two incompatible world views. However, they feel no difficulty when passing from one language to another and are quite able to express the same thing in each of the languages they speak.

So, if we refer to the theory of linguistic relativity, the possibility of translation from one language to another is denied. Finally, the thesis that two languages do not resemble each-other in anything also negates the cultural borrowings among people with different languages. Cultures, like people, give and take between them (Ramushaj 2004, 337).

The hypothesis of linguistic relativity is much more detected in the lexical subsystem and more precisely in the phraseology. Albanian and English language also have many common features which derive, first of all, from the language inherited unit, the so called linguistic universals.

\section{Prefixation in English and Albanian language}

Prefixation is a special affixation formation subtype among suffixation and prefixo-suffixation. In Albanian language it is an important derivation subtype, but not as suffixation. The prefixes of the English language are classifying; In most cases there is no change of the word class involved. (Kortmann 1999). As for their meaning and function, linguists notice that there are living prefixes, productive prefixes and fossilised ones in certain words. It is difficult to define the exact number of prefixes in English language, though there are more prefixes than suffixes. OED registers 167 prefixes, but according to Marchand (1969) there are 65 such. Prefixes in Albanian language are quite less in quantity, only one third of suffixes. Moreover, they do not have the same level of productivity as suffixes do, though prefixation remains a very important word-formation process especially in creating technical and scientific terminology. Aleksander Xhuvani has accounted 68 prefixes in his book "Prefixes of Albanian language", but many of these are not in use today such as (n-, m, s-, a-) (Shqerra 2009). 


\subsection{How does the Albanian language respond to the multiplicity of English prefixes?}

1. By means of the Albanian coorrelative prefix such as in .:inter-ndër ; anti-kundër, etj.

2. By means of polisemic affixes, which means that for two or more English affixes, there is just one Albanian affix, for eg.: sh, zh, ç (shfaqem, zhvishem, çarmatos) - a,un,de.

3. Third, Albanian language borrows affixes a) from the English language together with the word itself; b) it borrows from other neo-latin languages, from which even English language does.

\section{Classification of Prefixes in English}

Linguists of English language refer to these different categories of English prefixes in terms of generic denotational meaning: (Quirk, 1985:1540-1546)

\subsection{Prefixes of attitude: pro, anti, contra,counter, co.}

Pro-pro; (of latin origin); pro-choice, pro-life, pro-market; Pro; Pro jete, pro nesh(infavor of us), votoj pro. Anti (of greek origin); It is mostly added to nouns, adjectives and verbs. anti-aircraft - kundërajror, anti-social- kundërshoqëror. An Albanian prefix can also be used as in anti- kundër; kundrasocialiste. Contra (of latin origin) - Kunder; kundershtim Counter- clockwise ; counterbalance ; It can be alone such as in: He acted counter to your advices- Ai veproi ne kundershtim me keshillat e tua. Kunder- në drejtim të kundërt me akrepat e orës ;kunderpeshe. It can also be used as a preposition. Co- Bashke, cooperate - bashkepunoj, co-pilot- bashkepilot, co-author-bashkautor, cooperationbashkepunim; It is added to nouns and verbs.

The prefix anti-is very productive with adjectives ending in - ist. For example: anti-imperialist--anti-imperialist etc. These examples are taken from English-Albanian, dictionary of Pavli Qesku (EDFA 2002). Some of the foreign prefixes are assimilated by the Albanian word-formation system in such a high level that they have started to form new words based on native roots such as: antikombëtar (anti-national), panshqiptar (pan-Albanian), etc. However, another trend noticed in the modern Albanian language is the replacement of the borrowed prefixes by Albanian ones, for eg.: kundërajror, kundërgaz (antiajror, antigaz), ndërkontinental, ndërmolekular,(interkontinental, intermolekular), çmilitarizim,shpolarizim (demilitarizim, depolarizim) etc. (Fonetika dhe gramatika e gjuhes shqipe, Akademia e shkencave, 1976).

\subsection{Reservative and deprivative Prefixes: un, de, dis.}

Un; to untie, to unpack, to unhorse, to unscramble, to unlock. It is added to verbs, abstract nouns. Untie-zgjidh, unpackcpaketoj; unlock-hap; unscramble-ndaj.

De- Sh ,ç, zh: It is of roman origin; it is added to verbs and nouns to create verbs of reservative meaning. Eg. dehumidify thaj ajrin; deform- shformoj; defrost-shkrij; defuse-çaktivizoj; debarkment-shkarkim; dehumanize-çnjerezoj; defendant-i paditur. The prefix de in English finds three Albanian equivalent prefixes,(sh, ç, zh,pa).

Dis- mos, keq; It is added to nouns and it is a negative polisemantic prefix of roman origin which is semantically linked with the prefix de-,in-, and un-. 'Dis' is not a very productive prefix, e.g.: disaffirm-kundërshtoj, disaffectionpakënaqësi, disproportion-shpërpjestim, mospërputhje ; disbursement-shpagim, discolouration-çngjyrosje.

\subsection{Negative Prefixes: a-, dis-, non-, un-}

A: atheist, amoral, asymmetry, apolitical, asexual; It is added to adjectives and nouns; Dis: disloyal, distrust, disagree, dislike, disfavour, disadvantage; added to: adjectives, abstract nouns, verbs; Un: in-, il-(before l), im-(before p), ir-(before r); unfair, unassuming, unexpected, unproductive, insane, injustice, intolerance, impatience, imperfect, irregular, illegal, incapable, illogical, improper, irrelevant. These are added to: adjectives, participles (only un-); Non: non-stop, noninterference, non-aggression, non-smoker, non-drip (paint), non-person, non-event; This prefix is added to various types of words and expressions, mainly nouns and verbs.

In addition, there is a considerable number of foreign prefixal elements such as: a-, anti-, de-, dez-, dis-, pro-, pan-, trans-, ultra-, poli-, super-, auto-, inter-, etc. These are usually borrowed with the word they are pre-attached as in: anormal-normal, dezinfektoj-infektoj (disinfect - infect), disharmoni-harmoni (harmony-disharmony); in this case the 
foreign prefixal element is quite distingushable. Also, when there are used two derived words with the same root as in import-eksport (import-export), the foreign prefixes are easily distinguished even in terms of Albanian word-formation system.

A: atheist, amoral, asymmetry, apolitical, asexual; The prefix a- is added to greek root words, that is why it is not very productive in the modern English. Prefix a- forms scientific and technical words. janë përjashtime të kohëve të fundit). to adjectives and nouns. Eg.: atypical-jo karakteristik; apolitical-jo politik.

Dis: disloyal-pabesi; distrust-mosbesim; disagreement-mosmarreveshje; dislike-mospelqim; disfavor-mospranim, mospelqim; disadvantage-disavantazh.

Non: non-stop, non-interference, non-aggression, non-smoker, non-drip (paint), non-person, non-event; This prefix is added to various types of words and expressions, mainly nouns and verbs

Un: in-, il-(before I), im- (before p), ir-(before r); These are added to: adjectives, participles (only un-). Unfair- i padrejte, unassuming- $i$ thjeshte, modest, unexpected- i papritur, unproductive- joproduktiv, insane-i cmendur, injusticepadrejtesi, intolerance-intolerance, impatience-padurim, imperfect-joperfekt, irregular-i parregullt, illegal, incapable- i paafte, illogical-i pallogjikshem, improper-i pasakte, irrelevant- i parendesishem, pa lidhje.

\subsection{Pejorative prefixes: mis-, mal-, pseudo-, crypto-}

Mis- mismanagement, to miscalculate, , to mishandle, , misconduct,. It is added to verbs, abstract and participles. Keq misleading-keqdrejtim: to misgovern- keq qeveris, to misinform- keqinformoj.

Mal- Mal: means bad(ly), improper(ly): malpractice, malinformation, malnutrition, maltreatment, to malfunction, maladjusted, malformed. It is added to verbs, abstract nouns, participles, adjectives, but only words of latin origin.

Pseudo- pseudo-education, pseudo-intellectual, pseudo-science, pseudo-Gothic. It is added to nouns and adjectives. Pseudo (Is kept the same prefix even in Albanian); pseudo-intelektual, pseudoshkence.

Crypto-crypto-fascist, crypto-Catholic, cryptography. It is mostly added to nouns.

\subsection{Locative prefixes: ante, circum, fore, inter, intra, mid, out, over, retro, sub, super, supra, sur, ultra, under.}

Ante: antechamber, anteroom; It is added to: nouns; Circum: circumnavigate, circumlocution, circumcision; It is added to: verbs and nouns; Extra: extramarital, extracurricular, extrasensory, extra-pay; It is added to: adjectives and nouns; Fore $=$ in front, front part of: forefinger, foreskin, forecourt, forehead. It is added to nouns. In Albanian language the prefix para- fore

a) is added to verbs: (shikoj- parashikoj)

b) is added to nouns (lindje-paralindje); (provim-paraprovim)

c) is added to adjectives: (ushtarak- paraushtarak); (historik-parahistorik); (fundor-parafundor);

In: also il-, im-, ir- ingathering, indoors, in-patient (not impatient); added to: participles, nouns; Inter. interracial, international, interdisciplinary; added to: adjectives and nouns; Intra: intramural, intra-uterine, intravenous; It is added to: adjectives; Mid: midfield, mid-point, midway; added to: nouns; Out. outdoor, out-patient, outlook; added to: nouns; = to surpass: to outrun, to outnumber, to outgrow, to outdistance, to outbid; added to: verbs; Over. to overthrow, to overshadow, overcoat; added to: verbs, nouns; = excessive: overemphasis, over-anxious, to overcharge, to overfish; added to: nouns, verbs; Retro: to retroflex, to retrorocket, to retroject; added to: verbs; Sub: subway, subsoil, subconcious; added to: nouns, adjectives; = secondary, lesser in rank: sub-editor, subdean, subleader, sub-climax; added to: nouns; = subordinate part of: subcommittee, sub-plot, sublet, subtitle; added to: nouns; = below the norm: subhuman; Super. superstructure, superimpose, superterrestrial; added to: nouns, verbs, adjectives; beyond the norm:superhuman, superman, supergun, superstar; added to: nouns, adjectives; excessive, excessively: superconformity, superconfidence, supersensitive, superabundant, supercritical; added to: nouns, adjectives; Supra: supranational, supramundane; added to: adjectives; Sur. surtax, surcharge, surtitle; nouns, verbs; Tele: telecommunication, television; added to: nouns, verbs; Trans: transatlantic, transnational, transsexual; added to: adjectives, geographical names; Ultra: ultra-violet, ultra-sonic, ultra-modest, ultra-thin, ultra-modern, ultra-orthodox; added to: adjectives; Under. underground, undercarriage, underclothes; added to: nouns; = too little; undercharge, underpay, undercook, undervalue: added to: verbs; = subordinate: under-secretary, underclass.

\subsection{Prefixes of Size, Degree and Status: (arch, macro, micro, mega, mini, over/under, hyper, co, pro, vice)}


Arch-krye: archbishop (kryepeshkop), arch-rival, archangel (arkangels), archduke (kryeduke), arch-enemy( krye armik, armik i betuar) ; added to: nouns; macro-makro: macrocosm-(makrokozem), macro-economics(makro ekonimia); added to: nouns; micro: micro-computer (mikro kompjuter), microsurgery (mikrokirurgji), micro-economics (mikro ekonomi); added to: nouns; mega - mega: megastar (megastar, yll i madh), megastore (dyqan i madh); added to: nouns; mini-mini: minibreak (pushim i shkurter), minicab (minitaksi, taksi e vogel), miniskirt (minifund); added to: nouns; over/under: to overcook, to underheat-; added to: any verb of action; hyper-hiper, mbi, tej: hypercritical (me kerkesa te medha); added to: adjectives; co-bashke: co-founder (bashkethemelues), co-presenter(bashkeprezantues); added to: nouns, verbs; In Albanian language the prefix Bashkë - $\mathbf{c o}$ a) is added to nouns to create nouns with a collective meaning: udhetar bashkëudhetar; punetor -bashkepunetor; autor - bashkautor etc. b) is added to verbs to create others verbs with collective meanings.eg: bisedoj- bashkebisedoj; punoj - bashkëpunoj etc.

pro: pro-vice-chancellor; added to: nouns of latin origin; vice-zevendes: vice-president-zv president.

\subsection{Prefixes of Time and order: ante, ex, fore, neo, post, pre:}

Ex- former(ish): ex-wife-ish gruaja, ex-president-ish presidenti; human nouns; Fore: (para) before: to foresee-parashikoj to foretell-parathem, foregone-paraprij; Mid: middle: mid-afternoon-mesdite, midwinter mesdimri, midnight; Neo: new (neo), it is of greek origin, recent form of, revived: neo-colonialism (neokolonializmi), neo-conservative (neokonservativ), neo-fascist (neofashist); post (prapa, pas): after: post-war (paslufta), post-modernism (postmodernizmi), post-structuralist (post strukturalist). Sometimes the prefix post- is kept as a borrowed prefix as in postmodernism - postmodernizem, though the equivalent prefix in Albanian language is prapa, pas. Pre: (para) before, pre-arranged (parapergatis) before the time/period of: prepay (parapaguaj), pre-existing (paraekzistues), predate (paradatoj), preview (prove, vizionim), preschool (parashkollor), pre-war (paralufte), pre-marital (paramartesor). The translation is based on the P. Qesku "English-Albanian dictionary" 2002.

\subsection{Prefix of repetition: re- ri, e.g. rebuild (build-rindertoj), re-write-rishkruaj, etc.}

The Albanian prefix Ri- (re) is added to verbs: punoj - ripunoj. (rework, work again).

\section{Similarities and Differences between English and Albanian languages}

So the linguistic relativity is a language universal which should be used in language comparative studies. The similarities between the English and Albanian language firstly derive from the language inherited part. Secondly, it is because of the ongoing process of borrowing words from other languages. The linguists do not strongly support the full version of the linguistic relativity hypothesis, for otherwise there would be no cultural borrowings, no facts about bilingualism, no translations from English into Albanian and the vice-versa. It is true that different languages do not have identical morphological, syntactical and lexical structures, but this does not mean that they have nothing in common.

Both English and Albanian languages have neoclassical words (of the latin and greek origin), so they share the borrowing system of these languages. A mutual characteristic of the two languages is the borrowing phenomenon, the tendency of borrowing words and prefixes, but there are cases in the Albanian language, in which it is kept the Albanian prefixal element, such as in the prefix with a negative meaning A-: normal-anormal (jonormal); simetrik-asimetrik (josimetrik); fetar-afetar (jofetar). However, this tendency for both languages can be noticed in the large number of the borrowed prefixes together with the word. Another mutual characteristic is that several prefixes which come from the class of prepositions and particles, sometimes they do not change their the wordclass for example "hyper-", " multi" in English and jo- and pa- etc. In Albanian. This can be seen even in the Albanian language with the prefixal elements "para", or the latin and greek ones latinet e greket, "omni-"e "astro-, hydro". These are used in English and Albanian at the same time. In both English and Albanian wordformation the derivation type has been enhanced by means of new tools which come from compounding and aggregation. In the Albanian language there is no fixed boundary between prefixation and compounding for a good part of prefixes come from the class of prepositions. Moreover, some particles are turned into prefixes.(Shahini,2013)

A large number of prefixes have historically been affixes. Some others are international affixes part which come from other language borrowings. They are generally spelt as a whole word with the root in Albanian, though sometimes we find them devided by hyphen. Whereas in the English language there are no cases of seperately spelt words formed with prefixes. Here are some examples of English words spelt with hyphen non-moral, non-europian etc. Another 
characteristic is the placement of two prefixes or two suffixes before or after the root, for example: unpremeditated or antidisestablishment.

Un/pre/meditated - i pa/para/menduar (the prefixes un and pre are translated pa and para).

Anti/dis/establish/ment - opposition to disestablishment (kunder ndarjes se kishes nga shteti).

Apart from the similarities, there are differences as well between English and Albanian language in terms of words formed by prefixes. Many words formed by negative prefixes, in Albanian language they come translated by a negative suffix. For example,

unreasonable is translated i paarsyeshem, but harmless- i pademshem; endless - i pafund; flavourless - i pashije, shameless - i paskrupullt. As we see the English adjectives ending in less are translated by adjectives formed by negative prefixes.

\section{Conclusions}

There are a lot of difficulties deriving from the diversity of cultures, history, languages, when people from different ethnic and linguistic backgrounds come into contact and communicate with each-other. Linguists claim that English speakers think about the world in different ways from Albanian ones. Albanian language is spoken by a small population and its lexicon is rather smaller than that of the English language, and for this reason, during the translation process lexical or semantic equivalents are often unavailable. Thus, this fact gives priority to the necessity of understanding linguistic and cultural relativity, a theory which was inspired by Edward Sapir's hypothesis.

This paper aimed to give a contrastive analysis of the English and Albanian languages in terms of linguistic relativity in derived words by means of prefixation in English and Albanian language .The paper covered problems that occur during translation process in the words formed by means of prefixation. We considered the Quirk's classification of the prefixes that is the locative prefixes, the negative prefixes, the prefixes of attitude, reservative prefixes, pejorative prefixes, prefixes of size, degree and status, prefixes of time and order, prefix of repetition.

The linguists do not strongly support the full version of the linguistic relativity hypothesis, for otherwise there would be no cultural borrowings, no facts about bilingualism, no translations from English into Albanian and the vice-versa. It is true that different languages do not have identical morphological, syntactical and lexical structures, but this does not mean that they have nothing in common.

The hypothesis of linguistic relativity is much more detected in the lexical subsystem and more precisely in the phraseology. Albanian and English language also have many common features which derive, first of all, from the language inherited unit, the so called linguistic universals.

If we compare the number of English affixes to that of the Albanian affixes, then we have to say that the number of Albanian prefixes is quite less in number. However, prefixation in Albanian language remains a very important wordformation process especially in creating technical and scientific terminology.

In conclusion, the Albanian language does have the capacity of responding to the multiplicity of English prefixes by means of a variety of techniques as explained above; by means of the Albanian coorrelative prefixes for e.g: inter-ndër ; anti-kundër, of polisemic affixes, and by means of borrowing or borrowed affixes from other neo-latin languages, from which even English language borrows.

\section{References}

Webster's new 20 $0^{\text {th }}$ century, Unabridged Second Edition, De Luxe Color, William Collins and World Publishing Co., Inc., 1975

Ḉeliku M, Karapinjalli M, Stringa R, 2007, Tiranë "Gramatika praktike e gjuhës shqipe” Toena, pg. 303, 304, 305, 310, 327 - 328.

Quirk Randolf, Sidney Greenbaum, Geoffrey Leech and Yan Startvick. 1985, A Comprehensive Grammar of the English Language. London and New York Longman, pg. 1540-1546.

Shqerra,E. 2009 "C.A of wordformation in English and Albanian languages", pg.6, 32.

Akademia e Shkencave të Shqiperisë, 1976, Tiranë, "Fonetika dhe gramatika e gjuhës së sotme letrare shqipe", pg 35..38.

Qesku P, "English-Albanian dictionary" 2002.

Kortmann, Bernd, 1999, Linguistik: Essentials. Berlin: Cornelsen Verlag, pg 52.

Marchand, Hans, 1969, "The categories and types of present-day English word-formation (2-nd edition)

Ramushaj R, 2004, "Hyrje ne gjiuhesi", Tirane, pg.337.

Swoyer C, 2003, "The linguistic relativity Hypothesis" Stanford Encyclopedia of Philosophy. Accessed June 2010.

Shahini M, 2013, "Rreth dukurive morfo semantike ne gjuhen shqipe dhe angleze", pg.238,239.

Saussure, F,1986."Course in General Linguistics", edited by Charles Bally and Albert Sechehaye, Chicago and La Sale, Illinois.pg.74.

Sapir, E, 1949, "The status of Linguistics as science", University of California Press, pg.65.

Xhina, O, 2013, "Prefixation in English and Albanian languages", "Academic Journal of Interdisciplinary studies", special issue, vol.2, no.8. 